\title{
SPRAWOZDANIE Z MIĘDZYNARODOWEJ KONFERENCJI NAUKOWEJ REFLECTIONS ON THE MAN IN THE SLAVIC PHILOSOPHICAL THOUGHT, TRNAVSKÁ UNIVERZITA V TRNAVE, TRNAWA, 26 PAŹDZIERNIKA 2016 R.
}

26 października 2016 roku na Uniwersytecie Trnawskim w Trnawie na Słowacji odbyła się międzynarodowa konferencja naukowa nt. Refleksja nad cztowiekiem w stowiańskiej myśli filozoficznej. Sympozjum zostało zorganizowane przez Sekcję Etyki i Filozofii Moralnej Wydziału Filozoficznego Uniwersytetu Trnawskiego. Na spotkanie zaproszono przedstawicieli wielu środowisk naukowych z Czech, Polski, Rosji i Słowacji. Konferencja stanowiła pierwszy etap realizacji międzynarodowego projektu badawczego VEGA nr 1/0375/16 nt. Idea of Man between Profanum and Sacrum in Russian Thinking of 20th Century.

Skrót VEGA oznacza w języku słowackim Agencję Grantów Naukowych Ministerstwa Edukacji, Nauki, Badań Naukowych i Sportu Republiki Słowackiej oraz Słowackiej Akademii Nauk. Realizacja grantu nastąpi w latach 2016-2018. Kierownikiem projektu jest dr hab. Jaromir Feber - pracownik Uniwersytetu Trnawskiego oraz Uniwersytetu Technicznego w Ostrawie, natomiast do grupy wykonawców należą m.in. ks. prof. dr hab. Ryszard Moń oraz ks. dr hab. Andrzej Kobyliński z Instytutu Filozofii Uniwersytetu Kardynała Stefana Wyszyńskiego w Warszawie.

Uczestników sympozjum powitał dr hab. Jaromir Feber, który wyjaśnił w swoim wystąpieniu najważniejsze zadania związane z realizowanym międzynarodowym projektem badawczym oraz podkreślił wzajemną bliskość kulturową i cywilizacyjną narodów słowiańskich. 
Otwarcia konferencji dokonał prof. dr hab. Milan Kotuninca, dziekan Wydziału Filozoficznego Uniwersytetu Trnawskiego. Mówca przypomniał niezwykle bogatą i długą historię tego ateneum. Obecnie funkcjonująca uczelnia została utworzona de facto 25 marca 1992 roku, ale nawiązuje ona swą misją i nazwą do tradycji dawnego Uniwersytetu Trnawskiego, założonego 12 maja 1635 roku przez Petera Pázmana, arcybiskupa Ostrzyhomia (Esztergom) - węgierskiego miasta nad Dunajem. Prof. Kotuninca stwierdził, że po rozpadzie żelaznej kurtyny w 1989 roku przed narodami środkowoeuropejskimi stanęły nowe wyzwania dotyczące rozumienia wolności. Dobro człowieka i jego wyjątkowość powinny zawsze stać w centrum uwagi społeczeństw demokratycznych. Także w demokracji potrzebna jest rzetelna wiedza filozoficzna i humanistyczna, która może pomóc ludziom w tym, jak nie stać się ofiarą wielu nowych form manipulacji i zniewolenia.

Następnie głos zabrała prof. dr hab. Helena Hrehová, kierownik Katedry Etyki i Filozofii Moralnej Wydziału Filozoficznego Uniwersytetu Trnawskiego, która zwróciła uwagę na potencjał i specyfikę kultury słowiańskiej oraz na potrzebę jej promocji we współczesnym świecie. Mówczyni przypomniała główną idę I Zjazdu Słowiańskiego (Kongresu Słowiańskiego) - spotkania reprezentantów narodów słowiańskich w Pradze w dniach 2-12 czerwca 1848 roku, w którym uczestniczyli Chorwaci, Czesi, Polacy, Rosjanie, Serbowie, Słowacy i Ukraińcy. Najbliższy tego rodzaju kongres będzie miał miejsce w Sankt Petersburgu we wrześniu 2017 roku.

Sesji przedpołudniowej przewodniczył dr hab. Jaromir Feber. W programie konferencji dwa pierwsze wystąpienia zostały przewidziane dla naukowców z Instytutu Filozofii Petersburskiego Uniwersytetu Państwowego w Sankt Petersburgu w Rosji. Prof. dr hab. Igor Evlampiev zgłosił referat nt. Pojęcie jednostki i jej wolności w flozofii Borysa Cziczerina, natomiast dr hab. Alexander Rybas miał zaprezentować wystąpienie nt. Cztowiek jako problem filozofi pozytywnej w Rosji na poczq̨tku $X X$ wieku. $Z$ powodu nieobecności naukowców 
rosyjskich, ich referaty nie zostały zaprezentowane w ramach sympozjum, natomiast zostaną opublikowane pod koniec 2016 roku, wraz $\mathrm{z}$ innymi materiałami konferencyjnymi, w recenzowanym czasopiśmie naukowym Studia Moralia Tyrnaviensia.

Pierwszy referat nt. Lew Totstoj czy Iwan Iljin? Etyczne dylematy zwiqzane z przeciwstawianiem się ztu sita, wygłosił ks. prof. Ryszard Moń, który był także członkiem rady naukowej konferencji w Trnawie. Mówca poddał analizie niezwykle ciekawą dyskusję między Iwanem Aleksandrowiczem Iljinem (1882-1954) a Lwem Tołstojem (1829-1910) na temat zła, jego źródeł oraz sposobów przezwyciężania. Tołstoj utrzymywał, że zło jest pochodną amoralności i braku rozsądku. Przezwyciężenie zła jest możliwe tylko poprzez moralne samodoskonalenie się jak największej liczby ludzi. Tołstoj sądził, że zło musi ostatecznie ponieść klęskę, dlatego był zdecydowanym przeciwnikiem stawiania mu czynnego oporu, a zwłaszcza używania przemocy wobec drugiego człowieka, który dopuszcza się zła. Uważał, że przeciwstawiając się złu w imię demokracji i równości, nie powiększamy zakresu naszej wolności, lecz ją pomniejszamy. Dlatego proponował zastępowanie rewolucji politycznej rewolucją moralną.

Iljin sprzeciwiał się takiemu pojmowaniu sprawy. Dał temu wyraz w książce napisanej bardzo emocjonalnym stylem, zatytułowanej O sprzecizwianiu się ztu sita. Stwierdził w niej, że sprzeciwianie się złu jest nie tylko możliwe, ale nawet konieczne. Iljin był przekonany, że zło nie ma charakteru jedynie prywatnego, ale społeczny. Sam sposób ludzkiego istnienia, jak i sposób komunikowania się z innymi, pozostają w ścisłym związku. Nie można być zatem obojętnym na zło istniejące w innych, choćby nie dotyczyło to nas bezpośrednio. Złu trzeba przeciwstawić się siłą.

Drugim referatem w sesji przedpołudniowej było wystąpienie ks. prof. dr. hab. Josefa Dolisty z Uniwersytetu Karola w Pradze nt. Cel ludzkiego cierpienia $i$ wiary w myśli Bohuslava Reyneka. Prelegent z Pragi przedstawił najważniejsze idee głoszone przez czeskiego poetę, pisarza, malarza i tłumacza, który żył w latach 1892-1971. 
Podobnie jak Karel Čapek, Reynek uprawił refleksję filozoficzną w sposób pozaakademicki. Jego bogata twórczość, łącząca motywy religijne i filozoficzne $\mathrm{z}$ aspektami politycznymi, była zakazana w czasach komunizmu. $Z$ powodu przekonań antykomunistycznych Reyneka, cała jego rodzina została wypędzona $z$ domu. Jego dzieła zaczęły docierać do szerokiego kręgu odbiorców dopiero po aksamitnej rewolucji 1989 roku.

Kolejnym wystąpieniem w tej części obrad był referat prof. dr. hab. Heleny Hrehovej nt. Tajemnica i godność cztowieka w mysli kard. Jana Chryzostoma Korca. Mówczyni z Trnawy stwierdziła, że kard. Korec (1924-2015) jest jedną z najważniejszych postaci w historii narodu słowackiego w XX wieku. W jego pismach są obecne ciekawe i inspirujące treści filozoficzne. Korec podkreślał w swojej twórczości i działalności zagadnienie godności człowieka. Był przekonany, że wypływa z niej powszechna powinność szacunku wobec innych ludzi oraz obowiązek ochrony życia ludzkiego. Podejmował także dialog z myślą współczesną, m.in. z ateizmem egzystencjalnym Jean-Paula Sartre'a.

Czwartym wystąpieniem w sesji przedpołudniowej był referat nt. Walka Fiodora Dostojerwskiego o ludzi. Kilka uwag dotyczacych opowiadania "Sen śmiesznego cztowieka”, który wygłosiła prof. dr hab. Zlatica Plašienková z Uniwersytetu Komeńskiego w Bratysławie. Prelegentka stwierdziła, że w dziełach Dostojewskiego jest zawarta głęboka analiza filozoficzna, psychologiczna i psychoanalityczna bytu ludzkiego. Dlatego można uznać tego pisarza za antropocentrystę, ponieważ stawiał w centrum swoich zainteresowań istotę człowieczeństwa i podkreślał wyjątkowość osoby ludzkiej. Podobne stanowisko prezentowali dwaj wielcy rosyjscy filozofowie: Mikołaj Bierdiajew oraz Mikołaj Onufrijewicz Łosski. Warto dodać, że ten ostatni myśliciel w latach 1922-1942 mieszkał w Pradze i wykładał na Rosyjskim Uniwersytecie Ludowym, natomiast w 1942 roku przeniósł się z Pragi do Bratysławy i w latach 1942-1945 pracował naukowo na ówczesnym Uniwersytecie Słowackim w Bratysławie (obecnie Uniwersytet Komeńskiego). 
Piąty referat w porannej części konferencji wygłosiła prof. dr hab. Barbara Szostek z Uniwersytetu Śląskiego w Katowicach nt. Antoniego Kępińskiego fllozoforwanie o cztowieku. Mówczyni ukazała polskiego uczonego jako autora, który nie był filozofem, ale wykorzystywał wiedzę filozoficzną do głębszego zrozumienia nerwic, schizofrenii czy depresji. W jego badaniach medycyna łączyła się z filozofią i etyką. W konsekwencji jego podejście do różnego rodzaju chorób, bólu i cierpienia miało głęboki wymiar humanistyczny. Wszyscy chorzy - także ci, którzy cierpią z powodu chorób psychicznych - powinni być traktowani jako nasi bliźni, którym się w życiu nie powiodło. Józef Tischner twierdził, że Antoni Kępiński wiedział o człowieku więcej niż Zygmunt Freud, Martin Heidegger i Emmanuel Lévinas.

Kolejnym wystąpieniem w tej części obrad był referat dr. hab. Markéty Švamberk-Šauerovej z Wyższej Szkoły Wychowania Fizycznego i Sportu „Palestra” w Pradze nt. Analiza osobowości wychowawców w dzietach kard. Františka Tomáška i jej znaczenie dla wspótczesnej dziatalności edukacyjnej. Kard. Tomášek był arcybiskupem Pragi i prymasem Czech. Żył w latach 1899-1993. Jego zainteresowania naukowe dotyczyły m.in. pedagogiki. Kard. Tomášek jest autorem dwóch książek poświęconych tej problematyce: Pedagogika: Úvod do pedagogické praxe (1947); Pedagogika: Úvod do pedagogické praxe pro vychovatele a rodiče (1979). Prelegentka $\mathrm{z}$ Pragi zwróciła uwagę w swoim wystąpieniu na bogate wątki filozoficzne obecne w refleksji pedagogicznej byłego prymasa Czech.

Ostatni referat w sesji przedpołudniowej wygłosił ks. dr hab. Andrzej Kobyliński nt. Marksistowska koncepcja moralności rewolucyjnej wedtug Lwa Trockiego. Mówca podkreślit, że Lew Trocki (1879-1940) był jednym $z$ filarów systemu komunistycznego na pierwszym etapie jego rozwoju. W działalności rewolucyjnej Trockiego niezwykle ważną rolę odgrywała twórczość pisarska i publicystyczna. Tworzył on projekt nowego ładu na ziemi na gruncie filozofii marksistowskiej. Jego działalność wojskowa, polityczna i pisarska przyczyniła się do wymordowania milionów ludzi w wielu krajach świata. 
Kontynuując filozoficzne dzieło Marksa, Trocki analizował człowieka i świat w oparciu o podstawowe kategorie światopoglądu materialistycznego. Część swoich prac poświęcił także problematyce moralnej. Koncentrował się bardziej na krytyce moralności społeczeństwa kapitalistycznego niż na stworzeniu adekwatnego modelu etycznego dla bezklasowego społeczeństwa przyszłości, które - w założeniach koryfeuszy marksizmu - powinno być wolne od przemocy. Centralne miejsce $\mathrm{w}$ refleksji etycznej Trockiego zajmuje kategoria moralności rewolucyjnej, która odnosi się do zależności dialektycznej między celami i środkami. Zależność dialektyczna oznacza, że nie ma dobrych środków rewolucyjnych, jeśli nie towarzyszą one procesowi emancypacji mas, wyzwoleniu i wzbogaceniu moralnemu ludzi. W ramach moralności rewolucyjnej złe jest to, co czynią siły wrogie wobec komunistów, natomiast dobre jest to, czego dokonuja protagoniści rewolucji bolszewickiej.

Pierwszej części sesji popołudniowej przewodniczył dr Ondrej Marchevský z Uniwersytetu Preszowskiego w Preszowie. Obrady rozpoczęły się od wystąpienia dr hab. Alžbety Dufferovej nt. Analiza bytu ludzkiego we wspótczesnej filozofii rosyjskiej. Prelegentka z Uniwersytetu Trnawskiego nawiązała do idei V Zjazdu Słowiańskiego, który odbędzie się w Sankt Petersburgu we wrześniu 2017 roku. We współczesnej myśli słowiańskiej niezwykle ważną rolę odgrywa filozofia rosyjska. Zwraca na to uwagę m.in. prof. Siergiej Niżnikow z Rosyjskiego Uniwersytetu Przyjaźni Narodów w Moskwie, który prowadzi badania dotyczące m.in. Lwa Tołstoja oraz wpływu filozofii Immanuela Kanta na myślicieli rosyjskich XIX i XX wieku.

Drugim referatem po przerwie obiadowej było wystąpienie dr. hab. Tomáša Pružineca z Uniwersytetu Konstantyna Filozofa w Nitrze nt. Cztowiek i technika. Zarys problematyki w twórczości Mikotaja Bierdiajewa. Mówca stwierdził, że relacja człowieka do techniki i informacji jest dzisiaj przedmiotem wielu badań naukowych. Wiele cennych inspiracji dotyczących tej problematyki można znaleźć w twórczości Mikołaja Bierdiajewa, który zwracał uwagę na 
pozytywną i negatywną funkcję techniki, odrzucając w ten sposób stanowisko wielu przedstawicieli romantyzmu, którzy krytykowali en bloc rodzącą się na ich oczach nowożytną cywilizację techniczną. Dzisiaj człowiek powinien przejąć władzę nad techniką i dążyć do harmonii w różnego rodzaju ekosystemach.

Kolejny referat w tej części obrad wygłosił dr hab. Karol Orban z Uniwersytetu Karola w Pradze nt. Problem osobowości w dziennikarstwie na Stowacji. Prelegent przybliżył w swoim wystąpieniu postać Antona Hlinki (1926-2011), który w czasach komunistycznych pracował dla Radia Wolna Europa, natomiast po aksamitnej rewolucji i podziale Czechosłowacji na dwa nowe państwa, był bardzo ważną postacią w życiu intelektualnym i społecznym Republiki Słowackiej, walnie przyczyniając się do powstania mediów chrześcijańskich w tym kraju.

Czwartym wystąpieniem po przerwie obiadowej był referat nt. Antropologia filozoficzna w myśli rosyjskiej, który wygłosił dr hab. Jaromir Feber. Mówca stwierdził, że kluczowe znaczenia dla interpretacji bytu ludzkiego w filozofii rosyjskiej ma idea wszechjedności. Według tej koncepcji wszechświat jest kategorią ontologiczną oznaczającą zasadę formy wewnętrznej, doskonałej jedności mnogości. Jest to jedność absolutna lub transracjonalna, jedność rozdzielenia i wzajemnego przenikania się elementów. W konsekwencji nie ma izolowanych jednostek, ponieważ wszystko jest wzajemnie powiązane. Wbrew zasadom liberalnego indywidualizmu, teoria wszechjedności zwraca uwagę na to, że każdy jest odpowiedzialny za wszystkich. Zgodnie z tą koncepcją można dotrzeć do całego świata poprzez pojedynczego człowieka.

Kolejny referat w sesji popołudniowej wygłosił dr hab. Peter Neznik z Uniwersytetu Pavla Jozefa Šafárika w Koszycach nt. Filozofia Lwa Szestowa. Prelegent podkreślił, że wielki wpływ na myślenie filozoficzne Szestowa miała twórczość Williama Szekspira, która pomogła mu rozumieć świat wokół siebie. Drugim ważnym punktem odniesienia dla rosyjskiego filozofa był Immanuel Kant. Dzięki bogatej wiedzy humanistycznej i filozoficznej Szestow mógł analizować 
poglądy takich autorów jak Fiodor Dostojewski czy Fryderyk Nietzsche, czego ważnym świadectwem jest jego książka z 1903 roku pt. Dostojerwski i Nietzsche. Filozofia tragedii.

Ostatnim wystąpieniem w pierwszej części sesji popołudniowej był referat dr. Petera Greča z Instytutu Wychowania Humanistycznego w Sabinowie nt. Czy demokracja liberalna jest najlepszym systemem politycznym? Apoteoza demokracji w kontekście filozofii Mikotaja Bierdiajewa. Rosyjski filozof był przekonany o naturalnej nierówności ludzi. Dlatego nie zgadzał się m.in. z poglądami Jana Jakuba Rousseau. Bierdiajew twierdził, że nie ma ludu jako suwerena. Są tylko zatomizowane jednostki. Oczywiście demokracja ma swoje procedury, które są ważne i cenne, ale mogą one prowadzić do nowych form zniewolenia. W konsekwencji kryzysu współczesnej demokracji, dzisiaj mówi się coraz częściej o totalitaryzmie informacyjnym, medialnym czy finansowym.

Drugiej części sesji popołudniowej przewodniczyła dr hab. Alžbeta Dufferová. Obrady rozpoczęły się od wystąpienia dr. Pavola Krištofa z Uniwersytetu Trnawskiego nt. Rola Stowian w mysli Zaborskiego. Jonáš Záborský (1812-1876) był słowackim poetą, pisarzem, filozofem i teologiem. W bogatej twórczości tego autora można znaleźć wiele cennych treści dotyczących kształtowania się narodów w wymiarze kulturowym, duchowym i politycznym. Jedną z najważniejszych jego teorii była wizja współpracy narodów słowiańskich w oparciu o wspólny fundament tożsamości kulturowej i historycznej.

Autorem kolejnego wystąpienia nt. Ile twarzy maja rosyjscy narodnicy? był dr Ondrej Marchevský. Idea narodnictwa narodziła się w Rosji w drugiej połowie XIX wieku. Głównym ideologiem tego ruchu społeczno-politycznego był Aleksander Hercen. Narodnicy dążyli do zniesienia feudalizmu i budowy nowego państwa rosyjskiego. Zwolennicy tego nurtu łączyli idee antyfeudalne z krytyką burżuazyjnego postępu. Głosili także hasła przygotowania powstania chłopskiego, obalenia caratu i wprowadzenia tzw. socjalizmu agrarnego, którego zalążkiem miała być wspólnota chłopska. 
Trzecim wystąpieniem w tej części obrad był referat nt. Wspótczesny cztowiek i religia wedtug T. G. Masaryka, który wygłosił Tomáš Jahelka z Uniwersytetu Trnawskiego. Tomáš Garrigue Masaryk był w latach 1882-1914 profesorem filozofii na Uniwersytecie Karola w Pradze. Następnie stał się pierwszym i najdłużej urzędującym prezydentem Czechosłowacji. Od lat jest nazywany twórcą niepodległej Czechosłowacji. Ponadczasowym przesłaniem myśli filozoficznej Masaryka jest postulat życia w prawdzie oraz sprzeciw wobec rewolucji, która powinna być zastąpiona pokojowym dążeniem państw i narodów do demokracji.

Kolejny referat nt. Dr Andrej Žarnov - świadek wiary i prawdy zaprezentowała dr Eva Orbanová z Uniwersytetu Trnawskiego. Treści przedstawione w tym wystąpieniu były przejmującą egzemplifikacją niewyobrażalnych zbrodni systemów totalitarnych XX wieku i dramatu narodów słowiańskich w tym okresie historycznym. Dlaczego? Andrej Žarnov to pseudonim literacki Františka Šubíka (1903-1982) słowackiego poety, pisarza i profesora medycyny, mieszkańca Trnawy, jednego z dwunastu lekarzy, którzy w kwietniu 1943 roku udali się w składzie Międzynarodowej Komisji do Katynia, aby dokonać sekcji zwłok zamordowanych polskich oficerów i ustalić czas popełnienia zbrodni. Prof. Šubík złożył swój podpis pod protokołem końcowym Międzynarodowej Komisji Katyńskiej. $Z$ tego powodu był prześladowany przez komunistów po 1945 roku. Spędził dwa lat w więzieniu, ale nie uległ nowej władzy i nie odwołał swojego podpisu. W 1952 roku uciekł wraz z rodziną do Austrii, później do Włoch, Niemiec, a stamtąd do USA. W 1988 roku jego prochy zostały złożone w grobie rodzinnym na cmentarzu w Bratysławie.

Piąty referat w drugiej części sesji popołudniowej wygłosił mgr Bronislav Čaniga z Uniwersytetu Trnawskiego nt. Sztuka radości i zmyst humoru w życiu i myśli Tomáša Špidlika. Mówca przybliżył postać czeskiego kard. Tomáša Špidlíka (1919-2010), który był wielkim znawcą filozofii rosyjskiej, duchowości chrześcijańskiego Wschodu i teologii prawosławnej. W publikacjach tego autora można znaleźć także wiele ciekawych treści antropologicznych, dotyczących 
np. poczucia humoru jako jednej z umiejętności, która odróżnia człowieka od świata zwierząt.

Szóstym referatem w tej części obrad było wystąpienie dr Radki Minarovičovej z Uniwersytetu Trnawskiego nt. Motywy naturalne i refleksja nad cztowiekiem w twórczości Viliama Turčánego. Prelegentka przedstawiła w swoim wystąpieniu postać znanego słowackiego poety, pisarza, tłumacza i pedagoga. Viliam Turčány urodził się w 1928 roku. Jego twórczość charakteryzuje się głębokim wzajemnym przenikaniem wątków humanistycznych, filozoficznych i religijnych.

Ostatni referat nt. Milan Hamada - cztowiek kultury pisanej wygłosiła mgr Romana Puškelová z Uniwersytetu Trnawskiego. Mówczyni przybliżyła postać jednego z najbardziej znanych słowackich poetów i pisarzy. Hamada urodził się w 1933 roku. W czasach komunistycznych nie mógł publikować części swoich utworów. W jego pracach pojawia się wiele wątków filozoficznych związanych z krytyką ideologii, interpretacją transcendencji, rozumieniem świata wartości. Hamada zajmuje się też w swoich badaniach historią i specyfiką słowackiej kultury narodowej.

W ramach podsumowania konferencji prof. Helena Hrehová powróciła do kwestii tożsamości kulturowej i filozoficznej narodów słowiańskich. Jej zdaniem, Słowianie mają dzisiaj do odegrania ważną rolę na kontynencie europejskim, który podlega głębokiej transformacji. Konferencje naukowe i wspólne projekty badawcze, realizowane w ramach współpracy naukowej między ośrodkami uniwersyteckimi krajów Europy Środkowo-Wschodniej, stanowią ważny element wzajemnej integracji i pomagają poszerzyć wiedzę na temat kształtowania się specyfiki naszej części Europy na przestrzeni dziejów.

ANDRZEJ KOBYLIŃSKI

a.kobylinski@uksw.edu.pl

Uniwersytet Kardynała Stefana Wyszyńskiego w Warszawie, Instytut Filozofii

Wóycickiego 1/3, 01-938 Warszawa

DOI: 10.21697/spch.2017.53.2.41 